\title{
8. HEALTH STATUS
}

While most children are healthy, it is important to monitor health problems in children to detect emerging patterns of illness and to inform policy and planning of child health services. This section reports on asthma, oral health, disability, emotional and behavioural problems in children, and health status as measured by the Child Health Questionnaire (CHQ).

\section{Asthma}

Asthma is a chronic inflammatory disorder of the airways of the lung. Swelling of the airway lining, over-production of mucus, and contraction of the airway muscles in reaction to certain triggers, causes reversible airway narrowing and obstruction of breathing. The airways become hypersensitive, and the inflammatory process can cause permanent changes in the airways in the long term. ${ }^{1}$ The prevalence of asthma in Australian children is among the highest in the world and is increasing. ${ }^{2}$
The consequences of asthma in children can include: disturbed sleep; tiredness; and reduced participation in play at school, organised sport, and other activities. Asthma ranks among the top 10 problems managed by general practitioners and is a major cause for hospital admission in children. ${ }^{2}$

While asthma is not curable, it can be effectively managed. Current recommended management strategies include: increased use of preventer medications; reduced use of reliever medications where appropriate; use of structured written asthma management plans; avoidance of triggers (where known); self management education, and regular review by a general practitioner. ${ }^{1,3}$ Research has shown that most patients with asthma management plans found it useful for managing their asthma. ${ }^{4}$

The New South Wales Child Health Survey 2001 included questions that assessed prevalence, severity, and management of asthma among children aged 2-12 years.

\section{FIGURE 15}

CURRENT ASTHMA AND WRITTEN ASTHMA MANAGEMENT PLAN BY AREA HEALTH SERVICE OF RESIDENCE, CHILDREN AGED 2-12 YEARS, NSW, 2001

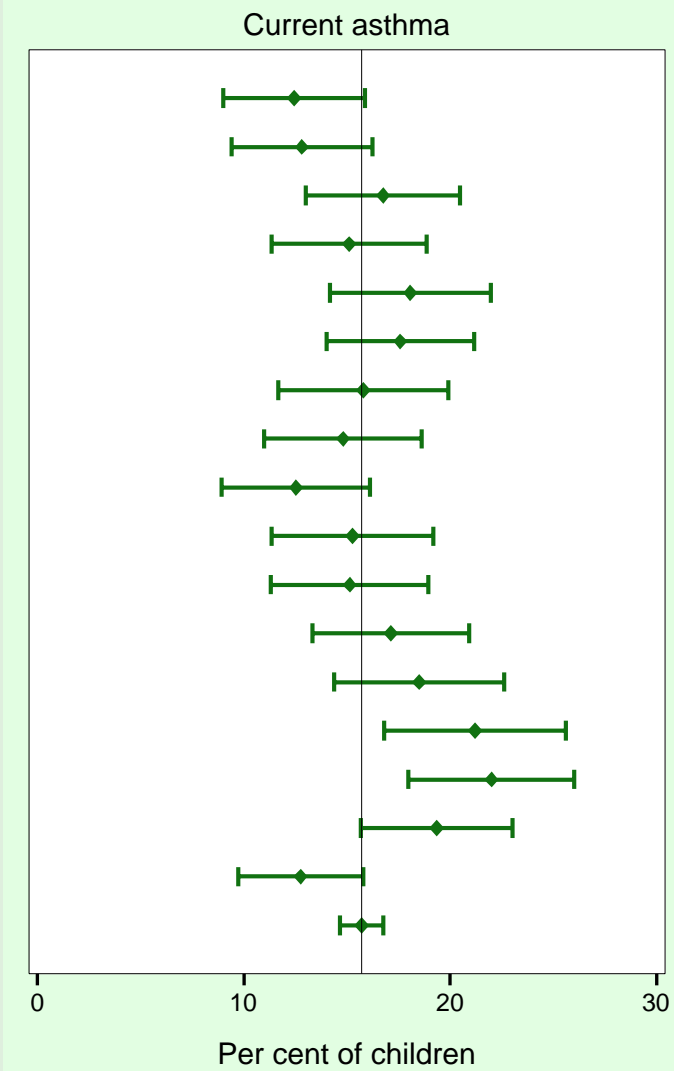

Health Area
Central Sydney
Northern Sydney
Western Sydney
Wentworth
South-West Sydney
Central Coast
Hunter
Illawarra
South-East Sydney
Northern Rivers
Mid-North Coast
New England
Macquarie
Mid-Western
Far West
Greater Murray
Southern
All NSW

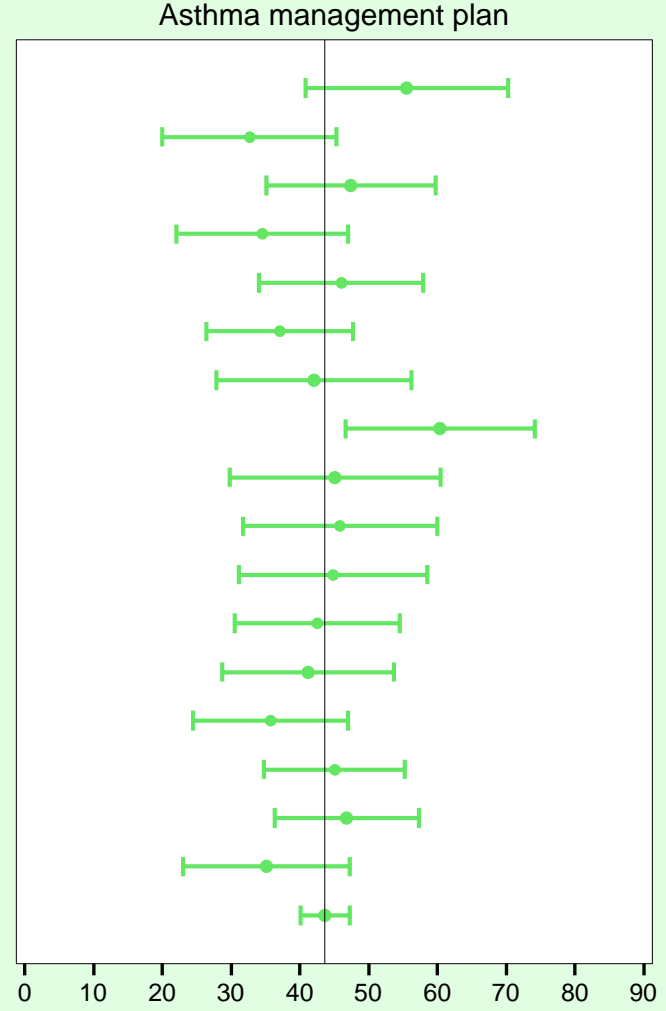

Per cent of children with current asthma

Note: Current asthma $=$ symptoms of asthma or medication for treatment or prevention of asthma in the last 12 months. Current asthma estimates based on 7916 respondents. Asthma management plan estimates based on 1296 respondents.

Source: New South Wales Child Health Survey 2001 (HOIST). Centre for Epidemiology and Research, NSW Department of Health. 


\section{TABLE 9}

CURRENT ASTHMA AND WRITTEN ASTHMA MANAGEMENT PLAN BY AREA HEALTH SERVICE OF RESIDENCE, CHILDREN AGED 2-12 YEARS, NSW, 2001

\begin{tabular}{|c|c|c|c|c|c|c|c|c|}
\hline Health Area & cent & LL 95\% Cl & UL $95 \% \mathrm{Cl}$ & $\begin{array}{r}\text { Estimates } \\
\text { Number }\end{array}$ & Per cent & LL 95\% Cl & UL $95 \% \mathrm{Cl}$ & $\begin{array}{r}\text { Estimates } \\
\text { Number }\end{array}$ \\
\hline \multicolumn{4}{|l|}{ Current asthma } & \multicolumn{5}{|c|}{ Asthma management plan } \\
\hline Central Sydney & 12.4 & 9.0 & 15.9 & 7000 & 55.5 & 40.8 & 70.3 & 3900 \\
\hline Northern Sydney & 12.8 & 9.4 & 16.2 & 12600 & 32.7 & 20.0 & 45.3 & 4100 \\
\hline Western Sydney & 16.7 & 13.0 & 20.5 & 15300 & 47.4 & 35.1 & 59.7 & 7200 \\
\hline Wentworth & 15.1 & 11.4 & 18.9 & 20400 & 34.5 & 22.0 & 47.0 & 7000 \\
\hline South-West Sydney & 18.1 & 14.2 & 22.0 & 19800 & 46.0 & 34.1 & 57.9 & 9100 \\
\hline Central Coast & 17.6 & 14.0 & 21.2 & 9700 & 37.0 & 26.3 & 47.7 & 3600 \\
\hline Hunter & 15.8 & 11.7 & 19.9 & 7400 & 42.1 & 27.9 & 56.2 & 3100 \\
\hline Illawarra & 14.8 & 11.0 & 18.6 & 12300 & 60.4 & 46.6 & 74.1 & 7400 \\
\hline South-East Sydney & 12.5 & 8.9 & 16.1 & 6800 & 45.1 & 29.7 & 60.4 & 3100 \\
\hline Northern Rivers & 15.3 & 11.3 & 19.2 & 6300 & 45.8 & 31.7 & 59.9 & 2900 \\
\hline Mid-North Coast & 15.1 & 11.3 & 19.0 & 6200 & 44.8 & 31.1 & 58.5 & 2800 \\
\hline New England & 17.1 & 13.3 & 20.9 & 4900 & 42.5 & 30.5 & 54.5 & 2100 \\
\hline Macquarie & 18.5 & 14.4 & 22.6 & 3400 & 41.2 & 28.7 & 53.7 & 1400 \\
\hline Mid-Western & 21.2 & 16.8 & 25.6 & 1700 & 35.7 & 24.4 & 47.0 & 600 \\
\hline Far West & 22.0 & 18.0 & 26.0 & 6000 & 45.0 & 34.8 & 55.3 & 2700 \\
\hline Greater Murray & 19.3 & 15.7 & 23.0 & 8300 & 46.8 & 36.3 & 57.3 & 3900 \\
\hline Southern & 12.7 & 9.7 & 15.8 & 3700 & 35.2 & 23.1 & 47.3 & 1300 \\
\hline All NSW & 15.7 & 14.7 & 16.8 & 151900 & 43.6 & 40.1 & 47.2 & 66300 \\
\hline
\end{tabular}

Note: $\quad$ Current asthma $=$ symptoms of asthma or medication for treatment or prevention of asthma in the last 12 months. Current asthma estimates based on 7916 respondents. Asthma management plan estimates based on 1296 respondents.

Source: New South Wales Child Health Survey 2001 (HOIST). Centre for Epidemiology and Research, NSW Department of Health.

\section{Asthma prevalence}

Approximately one quarter (26.4 per cent) of parents or carers reported ever being told by a doctor or at a hospital, that their child had asthma. This proportion was higher in males (29.8 per cent) than females (22.8 per cent); and the proportion increased with age, from 17.3 per cent among children aged two years, to 29.6 per cent among children aged 12 years.

Overal 15.7 per cent of children were reported to have current asthma (symptoms of asthma, or medication for asthma, in the last 12 months). Again, this proportion was higher in males (18.4 per cent) than females (12.9 per cent). Among males, current asthma was most frequently reported in the 6-8 year age group, affecting just over 20.0 per cent of males in this age group. Among females, current asthma was most frequently reported in the 9-10 year age group, affecting around 15.0 per cent of females in this age group. The prevalence of current asthma varied among area health services, with generally higher rates reported in rural areas. Current asthma was most frequently reported in Mid Western (21.2 per cent) and Far West (22.0 per cent) Health Areas (Figure 15, Table 9).

The reported overall prevalence of current asthma was consistent with other recent studies in NSW, which reported prevalence of current asthma as 22 per cent in a study based in Lismore, ${ }^{5}$ and 18 per cent in a study based in Wagga Wagga (children aged $3-5$ years). ${ }^{2}$

\section{Asthma severity}

More than half of children with current asthma (59.3 per cent) were reported to have visited a general practitioner (GP) for an asthma attack in the last 12 months. This proportion was similar among males (59.2 per cent) and females (59.3 per cent). More than one in five children (23.3 per cent) with current asthma were reported to have three or more GP visits for asthma attacks in the last 12 months. Reported visits to emergency departments were less frequent: 16.1 per cent of males and 16.4 per cent of females were reported to have visited an emergency department for an asthma attack in the last 12 months.

For more than half the children with current asthma (58.2 per cent), asthma was reported to have limited the child's usual activities in the last 12 months. The mean number of days of limited activity for children with current asthma was 9.3 days, while the median number was two days. Around half the children with current asthma were reported to have had disturbed sleep in the last month as a result of asthma (48.2 per cent). The mean number of nights of disturbed sleep for children with current asthma was 2.9 nights, while the median number was 0 nights. 


\section{Asthma management}

Less than half the children with current asthma (43.6 per cent) were reported to have a written asthma management plan from their doctor. This proportion was similar among males (41.9 per cent) and females (46.1 per cent). It varied among area health services, from 32.7 per cent in Northern Sydney to 60.4 per cent in Illawarra Health Area (Figure 15).

Overall, 61.6 per cent of children with current asthma were reported to have used a reliever medication in the last month; with the proportion being slightly higher for females (63.8 per cent) compared with males (60.1 per cent). Approximately one-quarter (26.6 per cent-27.2 per cent of males and 25.6 per cent of females) were reported to have used a reliever on less than half the days of the last month, with a smaller proportion (27.7 per cent) reported to use the reliever more frequently (29.6 per cent of males and 24.8 per cent of females).

Of children with current asthma, 59.4 per cent (56.4 per cent of males; 64.3 per cent of females) were reported to use a preventer medication in the last month. Overall, 39.3 per cent of children were reported to use a preventer every day (42.8 per cent of males; 33.8 per cent of females), and 8.6 per cent to use a preventer on most days ( 7.1 per cent of males; 10.8 per cent females). Overall, 18.3 per cent used a preventer on less than half the days of the previous month (18.7 per cent of males; 17.7 per cent of females) and approximately one quarter (26.2 per cent) were reported not to use a preventer in the last month (24.4 per cent males; 29.1 per cent females).

\section{References}

1. Australian Department of Health and Ageing. Health Insite: Asthma. Web site at www.healthinsite.gov.au/ T.cfm?PID=4765, accessed 17 January 2002.

2. Woolcock AJ, Bastiampillai SA, Marks GB, Keena VA. The burden of asthma in Australia. Med J Aust 2001; 175: 141-5.

3. Gibson PG, Coughlan J, Wilson AJ et al. Self management education and regular practitioner review for adults with asthma. Cochrane Database of Systematic Reviews [computer file]. Oxford: Update Software, 2000.

4. Douglass J, Aroni R, Goeman D, Stewart K, Sawyer S, Thien F, Abramson M. A qualitative study of action plans for asthma. BMJ 2002; 324: 1003 .

5. Haby MM. Peat JK, Marks GB, Woolcock AJ, Leeder SR. Asthma in preschool children: Prevalence and risk factors. Thorax 2001; 56: 589-95.

\section{Oral health}

The oral health of Australian children has improved over recent decades, with a dramatic decline in the experience of dental caries. ${ }^{1}$ However, there are clear inequalities in oral health, with higher rates of dental caries in children living in socially disadvantaged areas, rural and remote areas, and among Aboriginal and overseas-born children. There is also evidence of differential access to dental services according to country of birth, language spoken at home, insurance status, and mother's educational status. ${ }^{1,2,3}$

The oral health of children is most commonly assessed by their experience of dental caries, expressed as a score for decayed, missing, or filled teeth (DMFT). However, it is not possible to measure experience of dental caries in a telephone survey such as the New South Wales Child Health Survey 2001. Accordingly, the survey focused on the use of dental health services, including the frequency and place of dental visits and the treatments received. Distinction was made between short assessments of oral health, made as part of the Save Our Kids Smiles (SOKS) program, which the NSW Department of Health introduced in 1996; and visits to dental professionals, during which a full oral examination is conducted. The SOKS program is based in schools or pre-schools and involves children in Kindergarten, and Years 2, 4, 6 and 8 being offered free oral health education, oral health assessment, and clinical care on a priority-based system. ${ }^{4}$

In the New South Wales Child Health Survey 2001, parents or carers were asked about any dental injuries suffered by their child in the previous 12 months. Other reports have shown that most injuries to deciduous (milk) teeth occur at home, while most injuries to children's permanent teeth occur at home or school. Falls are the most common cause, although bicycle and traffic accidents, sports accidents, and violence, are also common causes. ${ }^{2,5}$ Mouthguards prevent dental injuries but are not widely used outside a few organised sports. Sports in which participants are at most risk of dental injuries include: rugby union, swimming, rugby league, basketball, cricket, hockey, soccer, netball, squash, softball-baseball, and tennis. ${ }^{6}$

\section{Save Our Kids Smiles (SOKS) assessments}

In the New South Wales Child Health Survey 2001, parents or carers of children aged 5-12 years were asked whether their child had a dental assessment at school as part of the SOKS program in the last 12 months. The New South Wales Child Health Survey 2001 captured information about SOKS assessments occurring between March 2000 and September 2001. Changes in eligibility for SOKS assessments occurred during this period. In 2000, all NSW children in the respective years being screened were eligible, while in 2001, assessments were offered only to children in these grades in schools designated as 'high risk' for poor oral health.

Just over half (53.1 per cent) of all children aged 5-12 years were reported to have had a dental assessment at school, as part of the SOKS program, in the last 12 months. This proportion was higher among children aged 8-12 years (57.4 per cent) than those aged 5-7 years ( 45.8 per cent). The reasons for this age difference are unclear but may relate to the timing of the survey interviews relative to the timing of the conduct of SOKS assessments around the state. 


\section{FIGURE 16}

\section{PLACE OF LAST DENTAL VISIT, CHILDREN AGED 1-12 YEARS, NSW, 2001}

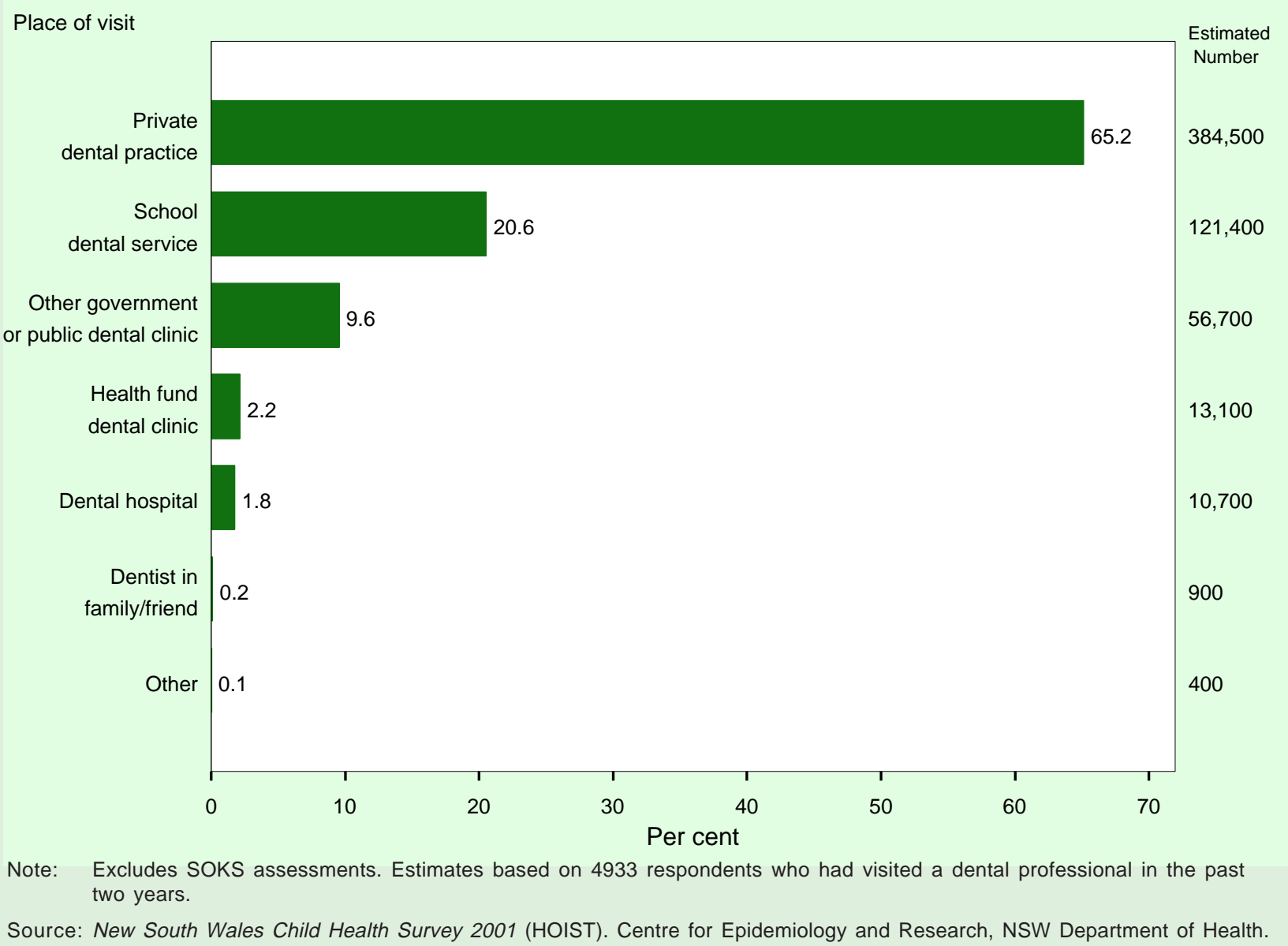

\section{Visits to dental professionals}

Overall, 61.6 per cent of children aged 1-12 years were reported to have ever visited a dental professional. This proportion was lower among indigenous children (52.5 per cent) than non-indigenous children ( 61.5 per cent), but was similar for children living in non-English speaking households (57.3 per cent) and English speaking households ( 60.7 per cent). The proportion of children reported as ever visiting a dental professional increased with age (4.0 per cent for children aged one year compared with 25.6 per cent for children aged 2-4 years, 67.6 per cent for children aged 5-7 years, and 90.0 per cent for children aged 8-12 years).

Forty-three (43.1per cent) of children aged 1-12 years reported visiting a dental professional (excluding SOKS assessment) in the last 12 months. This proportion increased with age (3.6 per cent for children aged one year compared with 20.8 per cent for children aged 2-4 years, 46.7 per cent for children aged 5-7 years, and 61.5 per cent for children aged 8-12 years).
Almost two-thirds (65.2 per cent) of dental visits (excluding SOKS assessments) made within the last two years were to private dental practices. One in five (20.6 per cent) were at school dental services and 9.6 per cent were at other public clinics. A minority reported attending a dental hospital (1.8 per cent) or a health fund dental clinic (2.2 per cent) (Figure 16). Of respondents who visited private dentists, 16.1 per cent were eligible for public dental care. The main reasons stated for using services provided by private dental professionals, when families were eligible for public dental care, were longer waiting times at public clinics (23.9 per cent), issues with continuity of care (15.8 per cent), better quality of care at private clinics (13.6 per cent), and poor access to public clinics (13.5 per cent).

The proportion of visits made at private dental clinics was considerably higher than that reported in National Dental Telephone Interview Survey 1999, where only around 40 per cent of NSW children aged 6-11 years had made their last visit to a private practitioner. ${ }^{3}$ 


\section{FIGURE 17}

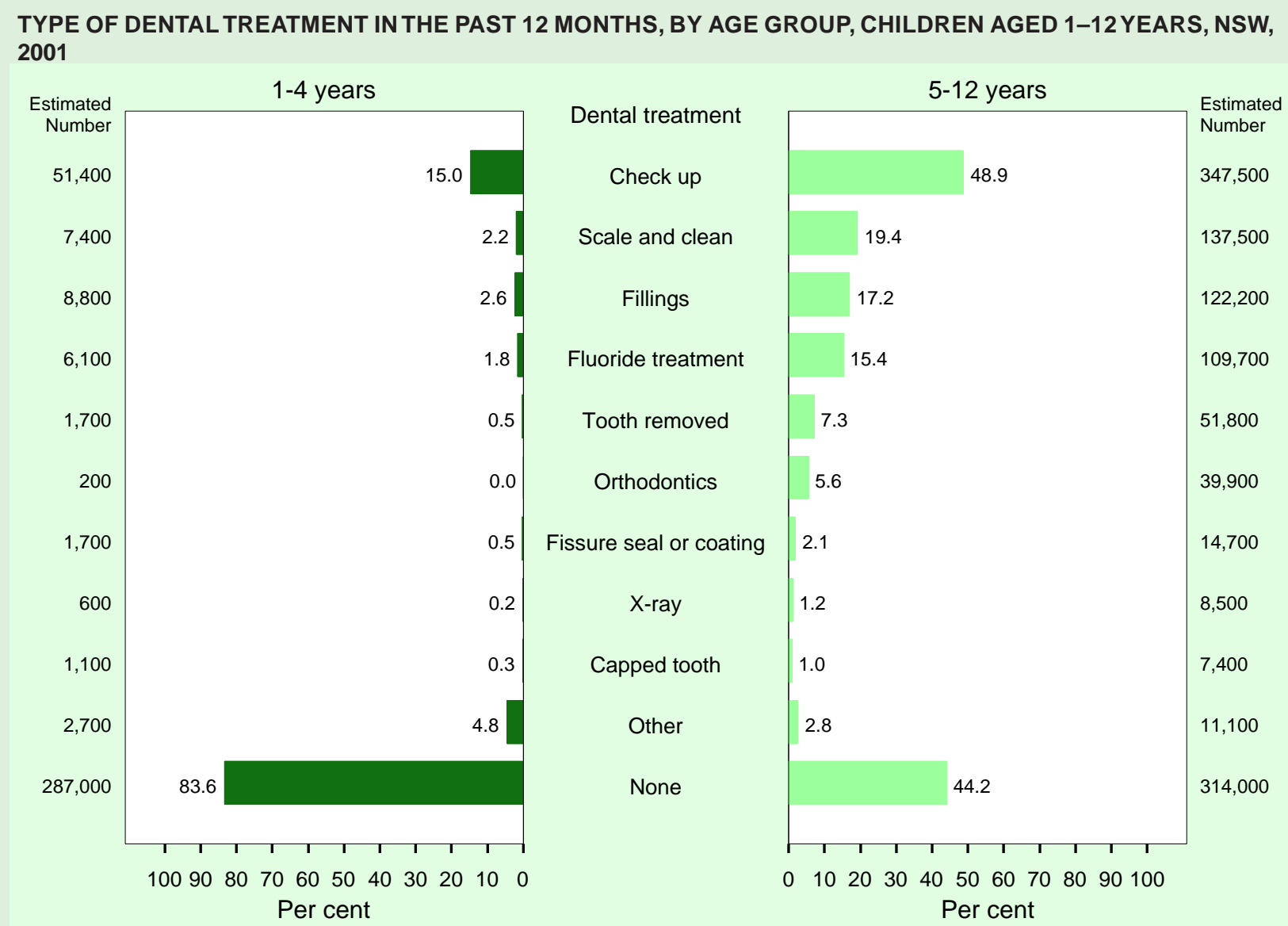

Note: Excludes SOKS assessments. Estimates based on 8689 respondents.

Source: New South Wales Child Health Survey 2001 (HOIST). Centre for Epidemiology and Research, NSW Department of Health.

\section{Dental treatments}

Overall, 37.9 per cent of children were reported to have had a dental check-up in the past 12 months (excluding SOKS assessments). This proportion varied by age group, with 15.0 per cent of children aged $1-4$ years and 48.9 per cent of children aged 5-12 years reported to have checkups. The most frequent dental procedures reported for children aged 5-12 years were scale and clean (19.4 per cent), fillings (17.2 per cent), fluoride treatment (15.4 per cent), removal of teeth (7.3 per cent), and orthodontics (5.6 per cent) (Figure 17). Children aged 5-12 years were around three times more likely than younger children to be reported to have had these dental procedures in the past 12 months.

\section{Dental injuries}

Overall, 3.9 per cent of children aged 5-12 years were reported to have seen a dental professional for treatment of a dental injury in the previous 12 months. This proportion was greater among children aged 8-12 years (3.7 per cent) compared with 5-7 years ( 2.4 per cent); and among males (3.9 per cent) compared with females (2.5 per cent).

\section{References}

1. Australian Institute of Health and Welfare Dental Statistics and Research Unit. Australia's oral health and dental services. AIHW Catalogue no. DEN 13. Adelaide: AIHW DSRU, 1998.

2. Australian Health Ministers' Advisory Council, Steering Committee for National Planning for Oral Health. Oral health of Australians: National planning for oral health improvement-Final report. Adelaide: South Australian Department of Human Services, 2001.

3. Australian Institute of Health and Welfare Dental Statistics and Research Unit. Oral Health and Access to Dental Care1994-96 and 1999 (Technical Report NDTIS 1999). Adelaide: AIHW DSRU, 2001. Available at www.adelaide.edu.au/ socprev-dent/dsru/publications.

4. NSW Department of Health. Review of the Save our Kids Smiles (SOKS) Program. Volume 1-Report. Sydney: NSW Department of Health, 2001.

5. Bastone EB, Freer TJ, McNamara JR. Epidemiology of dental trauma: A review of the literature. Aust Dent J 2000; 45: 2-9. 


\section{FIGURE 18}

\section{PREVALENCE AND SEVERITY OF SPEECH DIFFICULTIES BY SEX, CHILDREN AGED 2-12 YEARS, NSW, 2001}
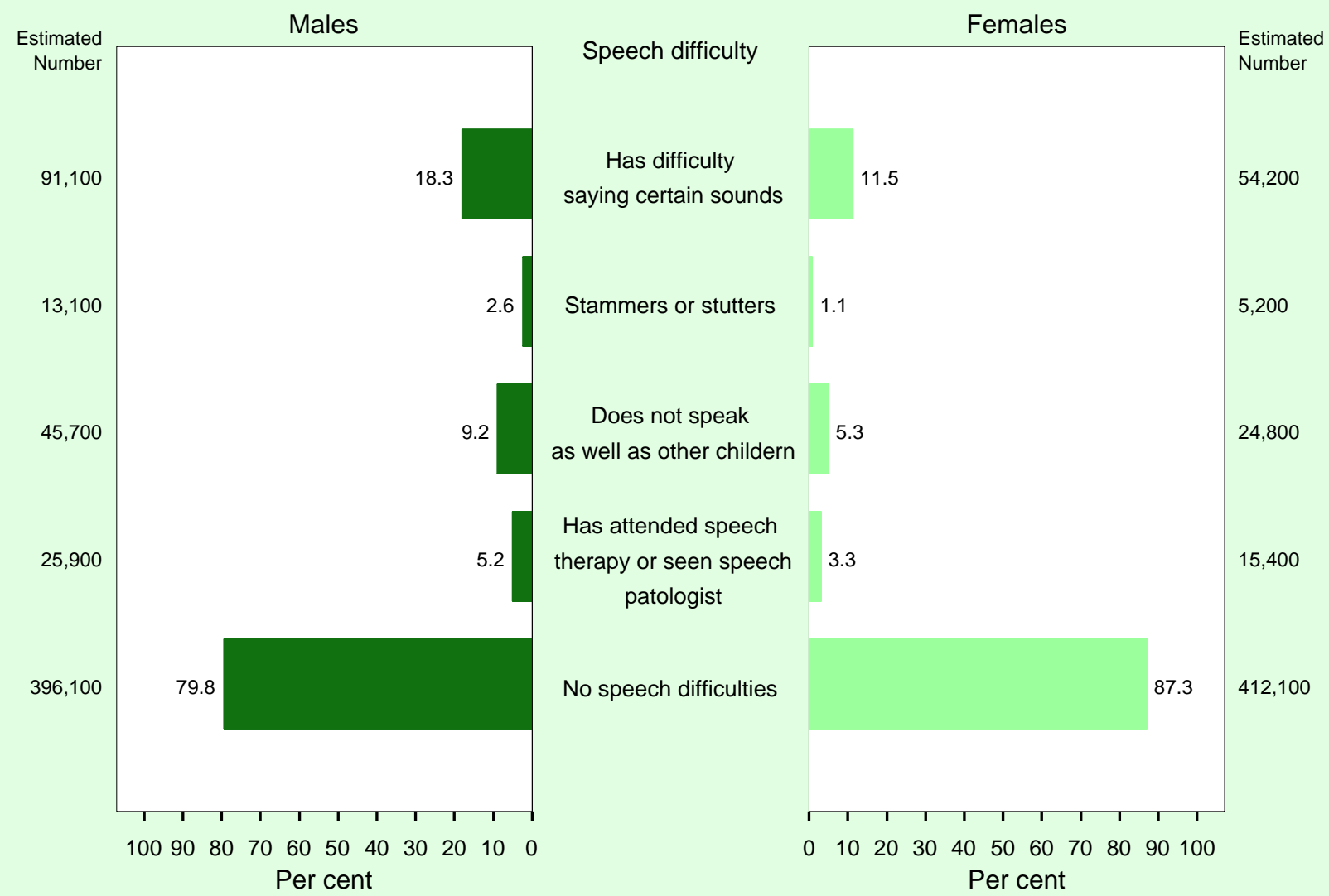

Note: Respondent could name more than one speech difficulty. Percentages will total more than 100 . Estimates based on 7916 respondents.

Source: New South Wales Child Health Survey 2001 (HOIST). Centre for Epidemiology and Research, NSW Department of Health.

6. Love RM, Carman N, Carmichael S, MacFadyen E. Sportsrelated claims to the New Zealand Accident Rehabilitation and Compensation Insurance Corporation, 1993-1996: Analysis of the 10 most common sports, excluding rugby union. N Z Dent J 1998; 94: 146-149.

\section{Disability}

The Australian Bureau of Statistics 1998 Survey of Disability, Ageing and Carers, reported that around one in 15 NSW children aged $0-14$ years (6.6 per cent) had a disability, with males ( 8.3 per cent) more frequently affected than females ( 4.8 per cent). Most of these children were restricted in their ability to perform core activities (such as self-care, mobility, or communication) and/or to participate in schooling. ${ }^{1}$

The New South Wales Child Health Survey 2001 included questions about visual, hearing, and speech impairments. These impairments can have adverse effects on communication skills, educational attainment, and quality of life. Published prevalence rates for communication disorders in children vary from 2-3 per cent to about 20 per cent, depending on the age of the children studied and the definition of the disorder. ${ }^{2}$ In the 1998 Australian Bureau of Statistics survey, sensory and speech impairments were the second most frequent cause of disability in children, after intellectual impairments. Around half of children with hearing or speech loss were restricted in their ability to communicate with others and/or had difficulties at school. ${ }^{3}$

The New South Wales Child Health Survey 2001 also included questions about ear infections. In otitis media (middle ear infection), fluid accumulates in the middle ear space, leading to conductive hearing loss. This may persist for weeks to months, after every episode of acute otitis media. Recurrent episodes may be associated with problems in the development of speech, language, and cognitive abilities. ${ }^{4}$

\section{Visual impairments}

Most children aged 2-12 years (92.6 per cent) were reported to have normal vision. Most of the children who did not have normal vision (7.4 per cent) were reported to wear glasses, and most of these ( 89.2 per cent) had no difficulty seeing words with their glasses on. 
Approximately one in 100 children ( 0.8 per cent) were reported to have difficulty seeing words, even with glasses on, or were blind in both eyes.

\section{Hearing impairments and ear infections}

Two-thirds (66.6 per cent) of children aged 2-12 years were reported to have had their hearing tested. One in 30 children (3.4 per cent) was reported to have any form of hearing loss, and 0.2 per cent were reported to currently wear a hearing aid.

Under half of all children aged $0-4$ years (42.0 per cent) were reported to have ever had an ear infection diagnosed by a doctor. Less than one in 10 (7.4 per cent) were reported to have ever had a discharge from an ear, or 'runny ear' (7.8 per cent of males; 6.9 per cent of females), while 2.2 per cent were reported to have had grommets inserted for treatment of chronic otitis media (2.6 per cent of males; 1.7 per cent of females).

\section{Speech difficulties}

Most children (83.4 per cent) were reported to have no speech difficulties. Overall, 16.6 per cent were reported to have a speech difficulty, with the rate being higher among males (20.2 per cent) compared with females (12.7 per cent). Compared with other children their age, 18.3 per cent of males and 11.5 per cent of females were reported to have difficulties saying certain sounds, while 9.2 per cent of males and 5.3 per cent of females were reported to not speak as well as other children. Also, 2.6 per cent males were reported to stammer or stutter, compared with 1.1 per cent of females. One in 20 males ( 5.2 per cent) and one in 30 females ( 3.3 per cent) were reported to have attended speech therapy or seen a speech pathologist (Figure 18).

\section{References}

1. Australian Bureau of Statistics. Disability Ageing and Carers, Summary Tables, New South Wales, 1998. Canberra: ABS, 1999.

2. Victorian Department of Human Services, Community Care Division Web site at http://hnb.dhs.vic.gov.au/comcare/ yafs_yf.nsf/6e, accessed 21 June 2002

3. Australian Bureau of Statistics. Disability Ageing and Carers, Disability and long term health conditions, Australia, 1998. Canberra: ABS, 2000.

4. Klein JO. The burden of otitis media. Vaccine 2000;19: S2-S8.

\section{General health status-The Child Health Questionnaire}

In the New South Wales Child Health Survey 2001, the general health status of children aged 5-12 years was assessed using the Child Health Questionnaire (CHQ), a multi-dimensional instrument that measures the functional health and wellbeing of children. The 28-item parentproxy form, CHQ PF28, is designed for administration to parents or carers of children aged 5-15 years. It has concepts of 'global health', 'physical functioning', 'rolesocial limitations (emotional-behavioural)', 'role- social limitations (physical)', 'bodily pain-discomfort', 'behaviour', 'global behaviour', 'mental health', 'selfesteem', 'general health perceptions', 'change in health', 'parental impact (emotional)', 'parental impact (time)', 'family cohesion', and 'family activities'. All questions are based on recall of the child's health over the past four weeks. ${ }^{1}$

The CHQ has been reported to be a reliable and valid measure of functional child health and wellbeing for the Australian population, encompassing children who are generally healthy and children with health problems related to physical and social functioning. ${ }^{2}$

This report does not report on the concept 'change in health', which measures general health now compared with one year ago, since this concept was not included in the New South Wales Child Health Survey 2001. In addition, we have only included one of two measures of general health (global health) and behaviour (global behaviour); and the report does not include the concepts of 'general health perceptions' and 'behaviour', both of which are scored differently.

The CHQ rating for each concept is reported by a mean and standard deviation (SD) (Table 10). This table provides population data for the parent-reported CHQ. These values can be used as a benchmark to compare subgroups of children or to monitor the health trends of the child health population aged $0-12$ years over time.

In the rating of 'global health', approximately half of all children were rated to have excellent health (51.6 per cent), one-third to have very good health (34.6 per cent), 11.1 per cent to have good health, and 2.1 per cent to have fair or poor health. The mean rating of 'global health' was slightly higher for children in rural areas (89.3), compared with urban areas (88.0). The mean rating of 'physical functioning' was slightly higher for females (96.4) compared with males (95.7) and among children aged 5-7 years (96.7) compared with children aged 8-12 years (95.6). The mean rating for 'body pain-discomfort' was slightly higher for males (84.4) compared with females (83.9) and among children aged 5-7 years (85.0) compared with children aged 8-12 years (83.6).

The mean rating for 'global behaviour' was higher for females (83.3) compared with males (77.5) and among children aged 8-12 years (81.1) compared with children aged 5-7 years (78.9). The mean rating for 'mental health' was similar for females (80.1) compared with males (79.0), and among children in rural areas (80.2) and urban areas (79.3). The mean rating for 'parental impact-emotional' was higher for females (83.0) compared with males (80.5) and for 'parental impact—-time' among children aged 812 years (93.1) compared with children aged 5-7 years (92.2). The mean rating for 'parental impact-time' was slightly higher for females (93.2) compared with males (92.2) and among children in rural areas (93.4) compared 
TABLE 10

\section{CHILD HEALTH QUESTIONNAIRE CONCEPTS AND MEAN RATING SCORES}

\begin{tabular}{|c|c|c|c|c|c|}
\hline Concept & $\begin{array}{l}\text { No. of questions } \\
\text { in the rating } \\
\text { (Rating scale) }\end{array}$ & Mean & SD & $\begin{array}{l}\text { Interpretation } \\
\text { - low score }(0)\end{array}$ & $\begin{array}{l}\text { Interpretation } \\
\text { - high score (100) }\end{array}$ \\
\hline Global health ${ }^{1}$ & $\begin{array}{l}1 \text { (Excellent, very } \\
\text { good, good, fair } \\
\text { or poor) }\end{array}$ & 88.3 & 0.2 & $\begin{array}{l}\text { Parent believes child's } \\
\text { health is poor }\end{array}$ & $\begin{array}{l}\text { Parent believes child's } \\
\text { health is excellent }\end{array}$ \\
\hline Physical functioning & $\begin{array}{l}3 \text { (Limited a lot, } \\
\text { limited some, limited } \\
\text { a little, not limited) }\end{array}$ & 96.0 & 0.2 & $\begin{array}{l}\text { Child is limited a lot in } \\
\text { performing all physical } \\
\text { activities including bending, } \\
\text { stooping and lifting, due to } \\
\text { health problems }\end{array}$ & $\begin{array}{l}\text { Child performs all types of } \\
\text { physical activities, including } \\
\text { the most vigorous, without } \\
\text { limitations due to health } \\
\text { problems }\end{array}$ \\
\hline $\begin{array}{l}\text { Role-social } \\
\text { limitations } \\
\text { (emotional- } \\
\text { behavioural) }\end{array}$ & $\begin{array}{l}1 \text { (Limited a lot, } \\
\text { limited some, } \\
\text { limited a little, not } \\
\text { limited) }\end{array}$ & 95.9 & 0.3 & $\begin{array}{l}\text { Child is limited a lot in school } \\
\text { work or activities with friends } \\
\text { as a result of emotional or } \\
\text { behavioural problems }\end{array}$ & $\begin{array}{l}\text { Child has no limitations in } \\
\text { school work or activities } \\
\text { with friends as a result of } \\
\text { emotional or behavioural } \\
\text { problems }\end{array}$ \\
\hline $\begin{array}{l}\text { Role-social } \\
\text { limitations } \\
\text { (physical) }\end{array}$ & $\begin{array}{l}1 \text { (Limited a lot, } \\
\text { limited some, limited } \\
\text { a little, not limited) }\end{array}$ & 95.6 & 0.3 & $\begin{array}{l}\text { Child is limited a lot in school } \\
\text { work or activities with friends } \\
\text { as aresult of physical health }\end{array}$ & $\begin{array}{l}\text { Child has no limitations in } \\
\text { school work or activities } \\
\text { with friends as a result of } \\
\text { physical health }\end{array}$ \\
\hline $\begin{array}{l}\text { Bodily pain- } \\
\text { discomfort }\end{array}$ & $\begin{array}{l}1 \text { (None of the time, } \\
\text { once or twice, a few } \\
\text { times, fairly often, } \\
\text { very often, every day } \\
\text { or almost every day) }\end{array}$ & 84.1 & 0.3 & $\begin{array}{l}\text { Child has body pain or } \\
\text { discomfort every day }\end{array}$ & $\begin{array}{l}\text { Child has no body pain or } \\
\text { discomfort }\end{array}$ \\
\hline Global behaviour ${ }^{1}$ & $\begin{array}{l}1 \text { (Excellent, very good, } \\
\text { good, fair or poor) }\end{array}$ & 80.3 & 0.4 & $\begin{array}{l}\text { Child's behaviour is poor } \\
\text { compared with other children } \\
\text { of the same age }\end{array}$ & $\begin{array}{l}\text { Child's behaviour is } \\
\text { excellent compared with } \\
\text { other children of the } \\
\text { same age }\end{array}$ \\
\hline Mental health ${ }^{1}$ & $\begin{array}{l}3 \text { (All of the time, most } \\
\text { of the time, some of the } \\
\text { time, a little of the time, } \\
\text { never) }\end{array}$ & 79.5 & 0.3 & $\begin{array}{l}\text { Child feels lonely, nervous, } \\
\text { bothered or upset all of the } \\
\text { time }\end{array}$ & $\begin{array}{l}\text { Child feels lonely, nervous, } \\
\text { bothered or upset none } \\
\text { of the time }\end{array}$ \\
\hline Self-esteem ${ }^{1}$ & $\begin{array}{l}3 \text { (Very satisfied, } \\
\text { somewhat satisfied, } \\
\text { neither satisfied nor } \\
\text { dissatisfied, somewhat } \\
\text { satisfied, very } \\
\text { dissatisfied) }\end{array}$ & 84.5 & 0.3 & $\begin{array}{l}\text { Child is very dissatisfied with } \\
\text { school abilities, friendships } \\
\text { and life overall }\end{array}$ & $\begin{array}{l}\text { Child is very satisfied with } \\
\text { school abilities, } \\
\text { friendships and life overall }\end{array}$ \\
\hline $\begin{array}{l}\text { Parental impact } \\
\text { (emotional) }\end{array}$ & $\begin{array}{l}2 \text { (None at all, a little } \\
\text { bit, some, quite a bit, } \\
\text { a lot) }\end{array}$ & 81.7 & 0.4 & $\begin{array}{l}\text { Parent experiences a lot of } \\
\text { emotional worry or concern as } \\
\text { a result of child's physical } \\
\text { health, emotional wellbeing or } \\
\text { behaviour }\end{array}$ & $\begin{array}{l}\text { Parent doesn't experience } \\
\text { emotional worry or concern } \\
\text { as a result of child's hysical } \\
\text { health, emotional wellbeing } \\
\text { or behaviour }\end{array}$ \\
\hline $\begin{array}{l}\text { Parental impact } \\
\text { (time) })^{1}\end{array}$ & $\begin{array}{l}2 \text { (Limits me a lot, limits } \\
\text { me some, limits me a } \\
\text { little, does not limit me) }\end{array}$ & 92.7 & 0.3 & $\begin{array}{l}\text { Parent experiences a lot of } \\
\text { limitations in time available for } \\
\text { own personal needs due to } \\
\text { child's physical health, } \\
\text { emotional wellbeing, or } \\
\text { behaviour }\end{array}$ & $\begin{array}{l}\text { Parent doesn't experience } \\
\text { a lot of limitations in time } \\
\text { available for own personal } \\
\text { needs due to child's physical } \\
\text { health, emotional wellbeing, } \\
\text { or behaviour }\end{array}$ \\
\hline Family cohesion & $\begin{array}{l}1 \text { (Excellent, very good, } \\
\text { good, fair, poor) }\end{array}$ & 76.9 & 0.4 & $\begin{array}{l}\text { Family's ability to get on is } \\
\text { rated 'poor' }\end{array}$ & $\begin{array}{l}\text { Family's ability to get on } \\
\text { is rated 'excellent' }\end{array}$ \\
\hline Family activities & $\begin{array}{l}2 \text { (Very often, fairly } \\
\text { often, sometimes, } \\
\text { almost never, never) }\end{array}$ & 84.5 & 0.4 & $\begin{array}{l}\text { The child's health very often } \\
\text { limits and interrupts family } \\
\text { activities }\end{array}$ & $\begin{array}{l}\text { The child's health never } \\
\text { limits or interrupts family } \\
\text { activities }\end{array}$ \\
\hline
\end{tabular}

Notes: Comparisons based on 5888 respondents. We did not report on the concepts 'change in health', 'general health perceptions', and 'behaviour',

1 The minimal score for these items is more than 0.

SD Standard deviation

Source: New South Wales Child Health Survey 2001 (HOIST). Centre for Epidemiology and Research, NSW Department of Health. 


\section{FIGURE 19}

HAD EMOTIONAL OR BEHAVIOURAL PROBLEMS INTHE LAST SIX MONTHS, BY AGE AND SEX, CHILDREN AGED 4-12 YEARS, NSW, 2001
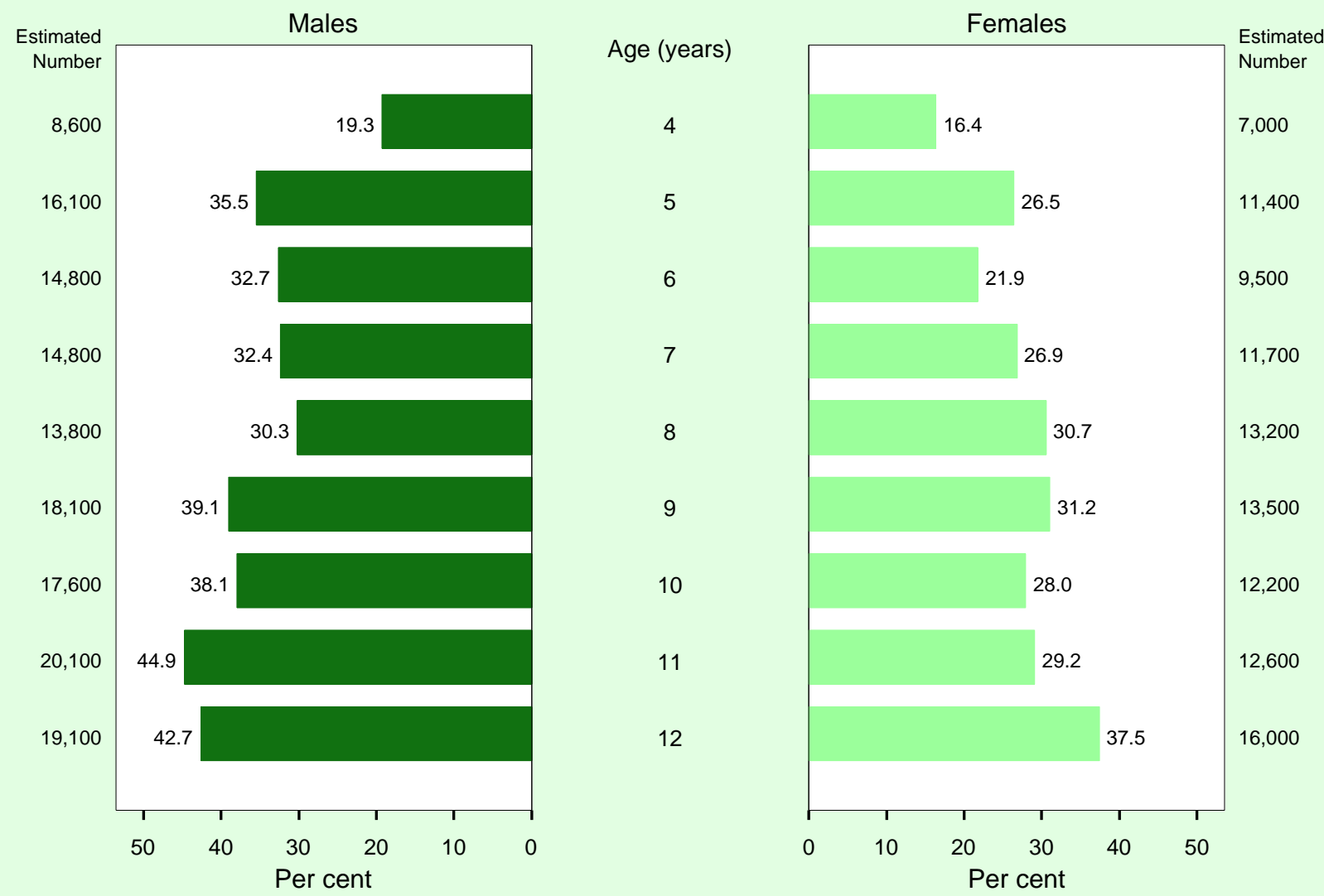

Note: Estimates based on 6503 respondents.

Source: New South Wales Child Health Survey 2001 (HOIST). Centre for Epidemiology and Research, NSW Department of Health.

with urban areas (92.5). The mean rating for 'family activities' was higher for females (86.) compared with males (83.0) and among children aged $8-12$ years (85.0) compared with children aged 5-7 years (83.7).

Similar results were reported from a self-completed parental survey in a large school-based sample in Victoria of children aged 5-18 years, using the PF50 (an expanded version of the PF28 questionnaire). ${ }^{2}$ The main differences were that the Victorian sample had lower mean scores for the concepts of 'role-social limitations (emotionalbehavioural)' (93.7) and 'self-esteem' (79.7), and slightly lower scores for 'body pain-discomfort' (82.3).

\section{References}

1. Landgraf JM, Abetz L, Ware JE. The Child Health Questionnaire (CHQ) User's Manual. First Edition. Boston, Mass: The Health Institute, New England Medical Center, 1996.

2. Waters E, Salmon L, Wake M, Hesketh K, Wright M. The Child Health Questionnaire in Australia: Reliability, validity and population norms. Aust N Z J Public Health 2000; 24: 207-210.

\section{Emotional and behavioural problems}

Childhood emotional and behavioural problems are one of the most common challenges that parents and carers face. Behaviour or school problems add stress to any family. The vast majority of childhood behavioural problems fall within the normal range and are appropriately dealt with by parents or primary care workers such as maternal and child and family health nurses, general practitioners, community health workers, and early childhood and childcare professionals. By understanding the nature of emotional or behavioural problems, and by getting the appropriate help and support, parents can better deal with these issues.

The child and adolescent component of the National Survey of Mental Health and Wellbeing 2000, ${ }^{1}$ provided the first reliable national data on the burden of mental health problems in children and adolescents in Australia. According to the results of the national survey, 15.0 per cent of boys aged 4-12 years and 14.4 per cent of girls aged 4-12 years have emotional or behavioural problems 


\section{FIGURE 20}

\section{SEVERITY OF EMOTIONAL OR BEHAVIOURAL PROBLEMS INTHE LAST SIX MONTHS, BY SEX, CHILDREN AGED}

4-12 YEARS, WHO HAD EMOTIONAL AND BEHAVIOURAL PROBLEMS, NSW, 2001
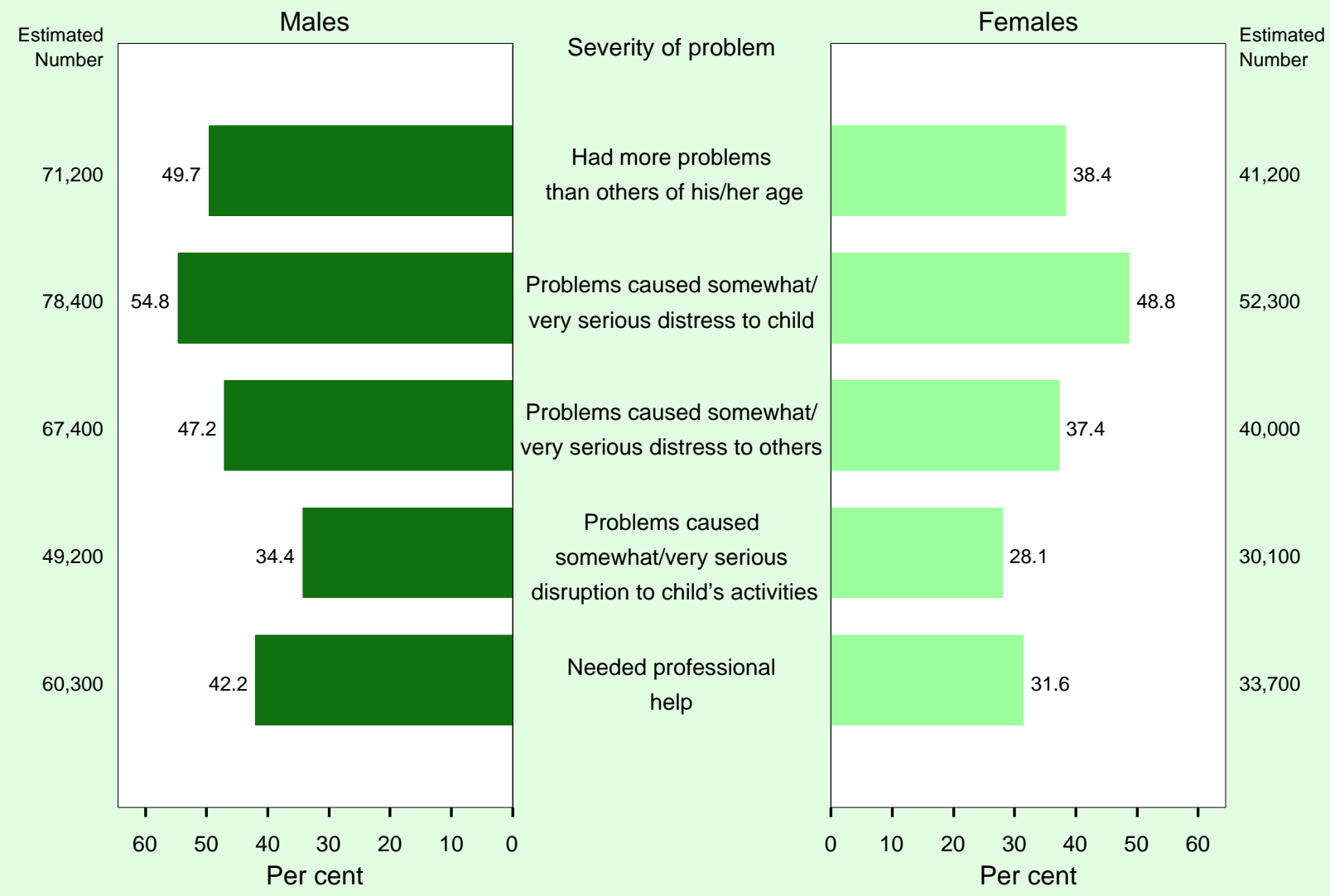

Note: Estimates based on 2082 respondents.

Source: New South Wales Child Health Survey 2001 (HOIST). Centre for Epidemiology and Research, NSW Department of Health.

in the 'clinical range' (that is, the range typically reported for those attending mental health clinics).

In addition to the CHQ items on emotional and behavioural health in the previous four weeks, parents and carers of children aged 4-12 years who participated in the New South Wales Child Health Survey 2001 were asked about emotional and behavioural problems experienced by their child over the previous six months, and about help that they needed for these problems.

Overall, almost one-third of children aged 4-12 years (31.4 per cent) were reported to have had any emotional or behavioural problems in the past six months, both clinical and non-clinical. These problems were more frequently reported among males (35.0 per cent) than among females (27.6 per cent), and their prevalence increased with age, from 17.9 per cent in children aged four years, to 40.2 per cent in children aged 12 years (Figure 19).

Among children reported to have had emotional or behavioural problems in the past six months, less than half
(44.9 per cent-49.7 per cent males; 38.4 per cent females) were reported as having had more of these problems than other children their age. In more than half of children who had emotional or behavioural problems (52.2 per cent54.8 per cent males; 48.8 per cent females), the problems were described as being somewhat or very serious in terms of causing distress to the child. Problems were less frequently described as being somewhat or very serious in terms of disrupting or causing distress to others (43.0 per cent-47.2 per cent males; 37.4 per cent females), or preventing the child from doing things usually expected of children their age (31.7 per cent-34.4 per cent males; 28.1 per cent females) (Figure 20).

More than one-third (37.6 per cent) of parents or carers of children aged 4-12 years, who were reported to have had emotional or behavioural problems in the last six months, stated that they thought their child needed professional help for these problems. Around two-thirds of these (68.3 per cent males; 61.9 per cent females) had obtained professional help. Among those who did not get help, the 


\section{FIGURE 21}

REASON FOR NOT BEING ABLE TO GET MORE HELP FOR EMOTIONAL OR BEHAVIOURAL PROBLEMS, CHILDREN AGED 4-12 YEARS, WHO NEEDED PROFESSIONAL HELP BUT DID NOT GET IT, NSW, 2001

Reasons given

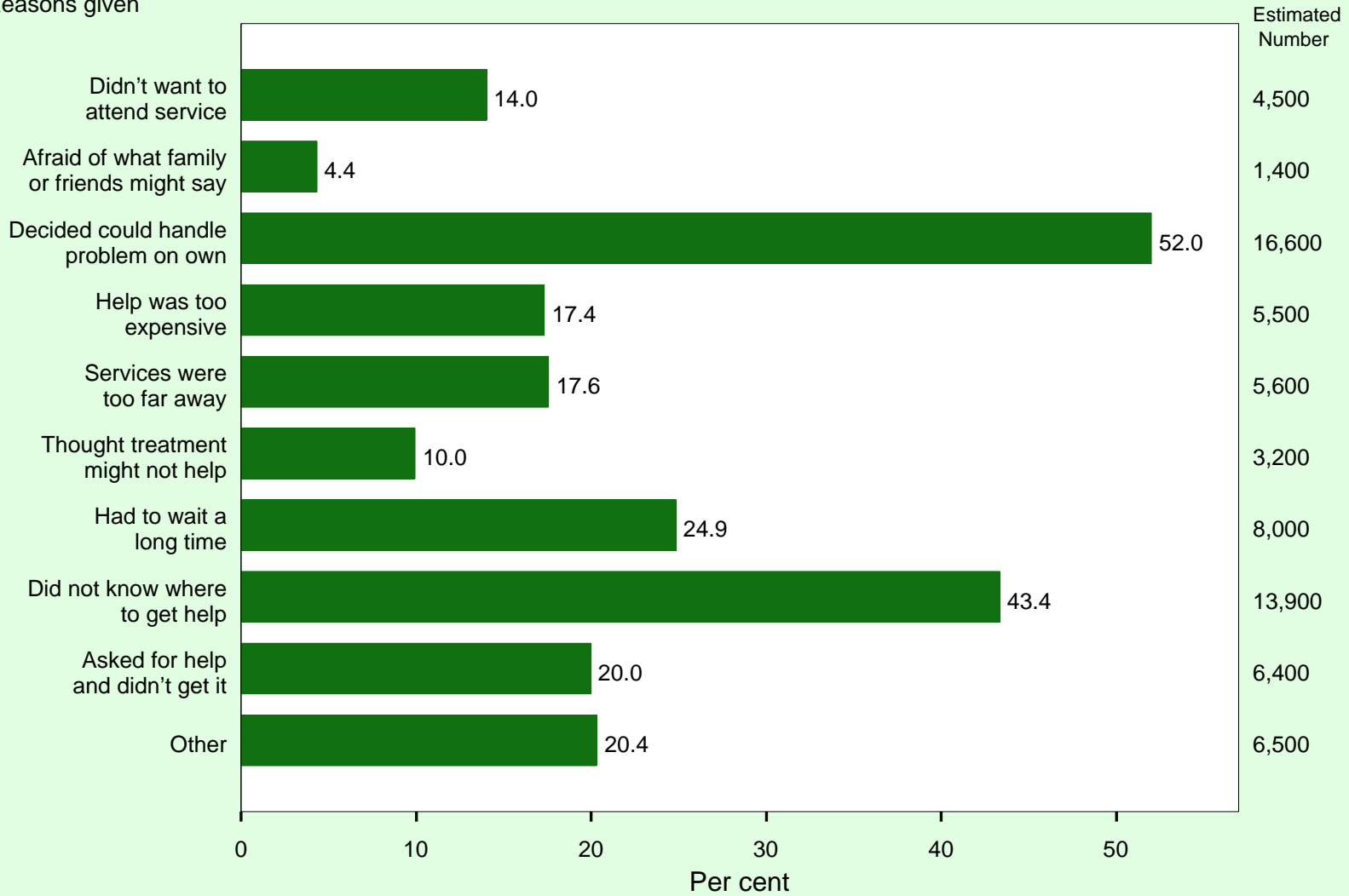

Note: Respondents could mention more than one reason. Percentages will total more than 100. Estimates based on 237 respondents.

Source: New South Wales Child Health Survey 2001 (HOIST). Centre for Epidemiology and Research, NSW Department of Health.

most common reasons cited were deciding to handle the problem on my own (52.0 per cent), not knowing where to get help (43.4 per cent), having to wait too long for an appointment (24.9 per cent), and asking for help but not getting it (20.0 per cent) (Figure 21).

\section{Reference}

1. Sawyer MG, Arney FM, Baghurst PA, et al. The Mental Health of Young People in Australia. Canberra: Mental Health and Special Programs Branch, Commonwealth Department of Health and Aged Care, 2000.

\section{Infant feeding and behavioural problems}

In the New South Wales Child Health Survey 2001, parents or carers of children aged 0-11 months were asked 17 questions regarding infant feeding and behavioural problems. For each feeding or behavioural problem, the parent or carer was asked what the most serious problem was, how serious the problem was, how difficult the problem was to manage, where they sought help, whether they still had a problem, and whether they required help to manage the problem.

Overall, 28.0 per cent of infants aged $0-1$ years were reported to have feeding problems and 35.1 per cent of infants were reported to have a behavioural problem. The main feeding problems reported were breastfeeding problems (63.0 per cent, of which 77.9 per cent were reported to be serious) and reflux (14.0 per cent, of which 90.1 per cent were reported to be serious). The main behavioural problems reported were settling difficulties (41.8 per cent, of which 51.2 per cent were reported to be serious) and colic (14.1 per cent, of which 73.1 per cent were reported to be serious).

Of the parents or carers who reported an infant feeding problem, 57.1 per cent said the problem was difficult to manage and almost all (99.0 per cent) sought help. Overall, 44.7 per cent of the parents or carers who had an infant behavioural problem said the problem was difficult to manage and, again, almost all (99.0 per cent) sought help. 
The main sources of help for infant feeding and infant behavioural problems was reported to be child and family health childhood nurses (66.7 per cent and 47.4 per cent respectively) or family and friends (30.8 per cent and 29.8 per cent respectively).

\section{Physical health of toddlers}

In the New South Wales Child Health Survey 2001, parents or carers of children aged 1-4 years were asked 17 questions regarding three main types of physical health issues relating to toddlers: eating or feeding problems, mobility problems, and other physical developmental problems. For each physical health problem, the parent or carer was asked to report the most serious problem, how serious the problem was, where they sought help, whether they still had a problem, and whether they required assistance to manage the problem.

Overall 7.5 per cent of parents or carers of children aged 1-4 years reported their child had eating or feeding problems; of these, 48.5 per cent were reported to be serious. A small proportion (1.6 per cent) of parents or carers reported their child had mobility problems (taking steps, walking or running); and, of these, 54.6 per cent were assessed by the parents to be serious. A slightly higher proportion (3.2 per cent) of parents or carers reported their child had other physical developmental problems (for example, trouble manipulating toys), of which 40.6 per cent were reported by the parents to be serious.

Of the parents or carers who reported a very serious or serious physical health problem with a toddler, 71.7 per cent had sought help for the feeding or eating problem, 82.4 per cent had sought help for the mobility problem, and 90.3 per cent had sought help for other physical developmental problems.

The main sources of help for physical health problems among toddlers were medical specialists $(31.8$ per cent for eating and feeding problems, 76.4 per cent for mobility problems, and 84.0 per cent for other physical developmental problems); and general practitioners (71.6 per cent for eating and feeding problems, 47.5 per cent for mobility problems, and 25.9 per cent for other physical developmental problems). 